\title{
The biochemical significances of the proximate, mineral and phytochemical composition of selected vegetables from Pakistan \\ Asia Atta ${ }^{\mathrm{a}, \mathrm{b}, \mathrm{c}^{\mathrm{c}}}$, Ghulam Mustafa ${ }^{\mathrm{c}, \mathrm{d},}$ Munir A Sheikh', Muhammad Shahid ${ }^{\mathrm{c}}$, Hang Xiao ${ }^{\mathrm{b}}$
}

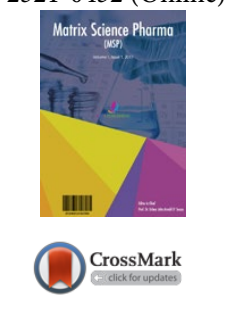

${ }^{a}$ Department of Biochemistry, Bahauddin Zakariya University, Multan-60800, Pakistan,

bDepartment of Food Science, University of Massachusetts Amherst, 100 Holdsworth Way, MA-01003, USA,

'Department of Biochemistry, University of Agriculture, Faisalabad-38040, Pakistan,

${ }^{\mathrm{d}}$ Department of Bioinformatics and Biotechnology, Government College University, Faisalabad-38000, Pakistan

This is an open access article distributed under the Creative Commons Attribution License, which permits unrestricted use, distribution, and reproduction in any medium, provided the original work is properly cited.

\section{ARTICLE DETAILS}

Article history:

Received 22 January 2017

Accepted 03 February 2017

Available online 05 February 2017

Keywords:

Free radicals, antioxidants, polyphenols, hyperglycemia, Vegetables

* Corresponding Author: Asia Atta, E-mail: asia.atta@bzu.edu.pk

\section{ABSTRACT}

Current study was designed to focus on the proximate, phytochemical and nutrient composition in addition to antioxidant properties of five selected vegetables viz Ipomoea batatas, Trigonella foenum-graecum, Daucus carota, Solanum Melongena and Brassica rapa rapa that are locally available and readily consumed in Pakistan. Nutritional analysis revealed that all the edibles were rich sources of crude protein, carbohydrate, fat and dietary fiber. Micro and macro minerals analysis also exhibited the significant presence of $\mathrm{Na}, \mathrm{K}, \mathrm{Ca}, \mathrm{Mg}$ and $\mathrm{P}$. Preliminary phytochemical screening unveiled the extraordinary incidence of alkaloids, saponins, tannins, flavonoids that was also proved by quantitative analysis. The biological assays bared a considerable antioxidant potential of selected green materials. Among vegetables, Trigonella foenum-graecum was proved to be superior while Brassica rapa rapa was considered to be inferior for phenolics and flavonoids content. Trigonella foenum-graecum also presented significant antioxidant activity with maximum reduction capacity and also having least IC50 as a result of inhibition of free radical scavenging by DPPH method. In contrast to $\alpha$-amylase, a significantly higher inhibition towards $\alpha$-glucosidase was shown by the selected samples; an impending remedial approach connected to postprandial hyperglycemia. In this scenario, the results of this study suggests that all the selected green materials have very good medicinal potentials, meet the standard requirements for drug formulation and serve as good sources of energy and nutrients. The outcomes of current work also revealed that plant derived foods enriched with phytoprotectants are effective to tailor specific healthy diet for the target population.

\section{Introduction}

Ethnomedicinal study is considered as an important tool for the discovery of plant based medication. Right from the commencement of ethnobotany, the documentation of folk medicinal acquaintance of plants, has discovered a variety of contemporary medications (Ahmad et al., 2013). Dietary guidelines encouraged the supplementation of plant-derived nutraceuticals not only to provide an insight regarding assuaging nature, nutritional worth, sustainability and safe status but also to modulate the onset of chronic ailments (Atta et al., 2016). Epidemiological studies also have correlated the consumption of the phytochemicals-based nutraceuticals particularly those from fruits and vegetables with declining incidences of several physiological threats (Zia-ul-Haq et al., 2014; Zhang and Liu, 2015). These bioactive ingredients like phenolics and carotenoids are diversified in nature which shows considerable antioxidative activity (Shahidi, 2009). Understanding the complex role of diet in chronic diseases is challenging since a typical diet provides more than 25,000 bioactive food constituents (Wang et al., 2012), many of which may modify a multitude of processes that are related to these diseases.

Dietary supplementation of phytonutrients is an emerging trend that provides multifaceted defensive mode against various maladies such as diabetes mellitus, cardiovascular disorders by inhibiting the oxidation owing to their intrinsic antioxidant potential (Peng, et al., 2008). Besides, they contribute indirect protection by activating the endogeneous defense systems by modulating the cellular signaling processes (Pal et al., 2012) and thereby enhancing the overall health status. In developing countries like Pakistan there is abundance of fruits and vegetables nevertheless have not yet been prodded meticulously for their health promoting properties. Purposely, current study was designed to focus on the proximate, phytochemical and nutrient composition as well as antioxidant properties of different edible species which are locally available and readily consumed in Pakistan.

\section{Material and Method}

\subsection{Collection and identification of plant materials}

Ipomoea batatas, Trigonella foenum-graecum, Daucus carota, Solanum Melongena and Brassica rapa rapa were purchased from the local market of Faisalabad, Pakistan, washed with distilled water, cut into small pieces and shade dried for several days. All samples were milled to a fine powder, mixed thoroughly and stored at $-80^{\circ} \mathrm{C}$. The $-20^{\circ} \mathrm{C}$ samples were used for the analysis.

\subsection{Preparation of crude polyphenol extracts}

Total phenolics from the vegetables were extracted by following the method of Noor et al. (2014) with slight modifications. Briefly, 25g of plant material was blended in chilled 70\% methanol $(1: 10 \mathrm{w} / \mathrm{v}, 5 \mathrm{~min})$, homogenized ( $5 \mathrm{~min}$ ) and then filtered under vacuum. The mixture was washed by centrifugation $(2500 \times \mathrm{g}, 10 \mathrm{~min})$ after adding the $50 \mathrm{uL}$ of $\mathrm{n}$-hexane twice. Finally, the extract was evaporated using a rotary evaporator at $45 \mathrm{oC}$ to dryness and stored at $-40 \mathrm{oC}$ until use.

\subsection{Proximate analysis of plants materials}

The dried plants powder was analyzed for its crude proteins, carbohydrates, crude fats, crude fibers and ash content by the following methods using the official methods of analysis of the Association of Official Analytical Chemists (AOAC, 2003).

\section{Total energy}

Total energy was calculated according to the following equations: Energy $($ Kcal $)=4 \times($ g protein + g carbohydrate $)+9 \times($ g lipid $)$ Energy $(\mathrm{KJ})=17 \times($ g protein + g carbohydrate $)+37 \times($ g lipid $)$

\subsection{Mineral Analysis}

Mineral contents of all the selected plant samples were determined by atomic absorption spectrometry, flame photometry and spectrophotometry according to the methods of AOAC (2010). The selected plants materials were digested in diacidic mixture of nitric acid and perchloric acid (1:1), and analyzed on atomic absorption spectrophotometer (Perkin Elmer, A Analyst 300) for Minerals (Iron (Fe), Zinc (Zn), Calcium (Ca), Chromium $(\mathrm{Cr})$, Manganese $(\mathrm{Mn})$ and Magnesium (Mg). Na and $\mathrm{K}$ analysis of the sample were done by the method of flame photometry by using the same wet digested food sample solutions. The results are presented in $\mu \mathrm{g} / 100 \mathrm{~g}$ of the original sample.

\subsection{Phytochemical analysis}

Phytochemical analysis for tannins, phenolics, flavonoids, saponins, carotenoids, terpenoids, and alkaloids were carried out according to known and standard methods. Alkaloids were determined by ethanol extraction and gravimetric measurement, as described by Harborne (2008). Tannins 
were estimated using the Folin-Denis spectrophotometric method (Shabbir et al., 2013). Saponin content was determined using the method of Khan et al., (2011). Total phenolic contents (TPC) and total flavonoid content (TFC) were determined by following the methods by Ho et al., (2010) and Barros et al., (2011) respectively.

\subsection{Antioxidant activity of plant extracts}

\subsubsection{DPPH radical scavenging assay of selected plant extracts}

The antioxidant activity of extracts was assessed by measuring their scavenging abilities to 2, 2-diphenyl-1-1-picrylhydrazyl stable radical (Ho et al., 2010). Briefly, 50uL aliquot of various concentrations of the samples was added to $5 \mathrm{~mL}$ of a $0.004 \%$ methanol solution of DPPH. After $30 \mathrm{~min}$ incubation period at room temperature, the absorbance was read against a blank at $517 \mathrm{~nm}$. The assay was carried out in triplicate.

\subsubsection{Determination of reducing power of selected plant extracts}

The reducing power of extracts was determined according to the procedure described by Barros et al. (2011). Briefly, $100 \mu \mathrm{L}$ of extract was mixed with $0.2 \mathrm{M}$ phosphate buffer $(5.0 \mathrm{~mL}, \mathrm{pH}: 6.6)$ and $1 \%$ potassium ferricyanide $(5.0$ $\mathrm{mL}$ ). After $20 \mathrm{~min}$ incubation $(50 \mathrm{oC}) 10 \%$ tricholoroacetic acid was added and centrifuged at $12,000 \mathrm{~g}(10 \mathrm{~min}, 5 \mathrm{oC})$. The upper layer of the solution $(5.0 \mathrm{~mL})$ was diluted with $5.0 \mathrm{~mL}$ distilled water and $0.1 \%$ ferric chloride $(1.0 \mathrm{~mL})$, and read at $700 \mathrm{~nm}$. The experiment was performed thrice.

\subsection{Statistical analysis}

The mean $\pm S D$ was calculated for triplicate experiments through Microsoft Excel 7.0. The statistical software Minitab version 13.1was used for computation and analysis of the antioxidant. Differences were analyzed by considering $\mathrm{P}<0.05$ statistically significant.

\section{Results and Discussion}

\subsection{Proximate analysis of selected vegetables}

The proximate analysis of selected vegetables indicate that as usual, there was a variation in crude protein content (Table 1$)$. Fenugreek $(28.07 \pm 0.03 \%)$ showed the maximum protein while turnip and carrot were at lowest position respectively. In sweet potato and eggplant similar percentage of crude protein $(12.21 \pm 0.11 \%$ and $13.85 \pm 0.03 \%)$ was observed respectively. According to the National Research Council of United States, crude protein less than $20 \%$ indicates low protein content of that feed stuff. However, present study was in the harmony with the finding of Sumayya et al. (2012) and Singh et al. (2013). The maximum carbohydrate was observed in carrot whereas it was the minimum in fenugreek. In developing countries 60 to $80 \%$ of energy is derived from dietary carbohydrates. The findings are in consonance with Sumayya et al. (2012) and Singh et al. (2013). The crude lipid contents were recorded similar in fenugreek, carrot and eggplant (2$3 \%$ ), while S. potato and turnip showed slightly less fat contents among the samples. Results of the lipid contents of present investigation were in line with that reported by Dike (2010).

Table 1. Proximate composition of selected vegetables (\%)

\begin{tabular}{|c|c|c|c|c|c|c|}
\hline Scientiffe name & \begin{tabular}{|l} 
Vernacular \\
Name
\end{tabular} & CP (\%) & Carb (96) & Fat (\%) & Fiber (\%) & Ash (\%) \\
\hline$I$ batatas & S potato & $1221 \pm 0111^{6}$ & 3). $74 \pm 109^{6}$ & $088 \pm 001^{6}$ & $388 \pm 010^{4}$ & $8 \times 3 \pm 016^{6}$ \\
\hline T. Genum graecum & Fenugreek & $19.07=0.03^{6}$ & $20.93=0.02^{2}$ & $2.50=0.01^{2}$ & $16.50 \pm 0.06^{6}$ & $13.00 \pm 0.01^{d}$ \\
\hline D. cerota & Carrot & $7.66=0.05^{2}$ & $51.84=0.02^{6}$ & $2.00=0.01^{2}$ & $18.5 \pm 0.02^{6}$ & $10.00 \pm 0.02^{c}$ \\
\hline S.Melengena & Eggplant & $13.85=0.03^{\text {b }}$ & $45.65 \pm 0.01^{6}$ & $3.50 \pm 0.02^{4}$ & $18.50 \pm 0.02^{6}$ & $8.50 \pm 0.02^{6}$ \\
\hline D. rapa & Turaip & $7.2910 .03^{2}$ & $40.7110 .04^{b}$ & $1.00-0.02^{2}$ & $12.5 \pm 0.03^{b}$ & $8.50 \pm 0.02^{c}$ \\
\hline
\end{tabular}

Recent research indicated that all the tested vegetables were good source of dietary fiber. Certain reports suggested that consumption of high fibrous diet have certain health promoting effects, including improved glucose tolerance in diabetics and the prevention of chronic diseases such as colon cancer (EFSA, 2010). Fenugreek and carrot had slightly higher ash content as compare to other samples which showed the similar percentage of ash content. Macronutrients are responsible for energy production in the human organism. In this regard, it should be highlighted that all the edible plants studied are foods with a very moderate energy value (Fig. 1), most providing around $186.56-321 \mathrm{kcal} / 100 \mathrm{~g}$.

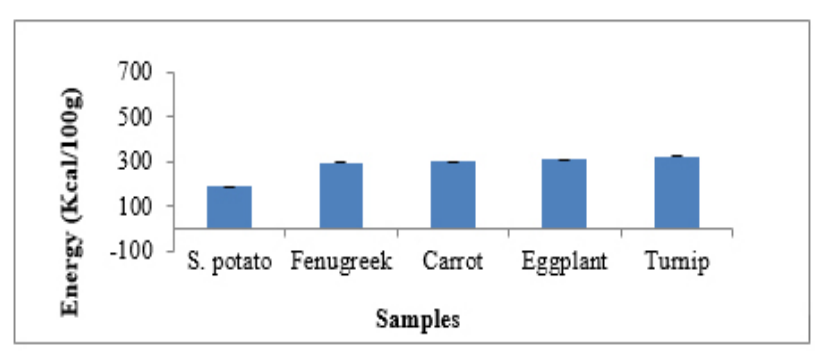

Fig 1. Energy values of the selected vegetable species.

\subsection{Mineral analysis of selected vegetables}

The mineral analysis of the vegetable species showed significant variability among different macro and microminerals (Table 2). Fenugreek was superior in $\mathrm{Cu}, \mathrm{Zn}, \mathrm{Fe}, \mathrm{Ca}, \mathrm{P}$ and $\mathrm{Mg}$ mineral elements among the edible samples. The trend was seems to be same as reported by Gala and Gujar, (2014). High level of Na and K in carrot and turnip was in accordance to Ekholm et al. (2007). The lowest values of $\mathrm{Cu}, \mathrm{Zn}, \mathrm{Fe}, \mathrm{K}$ and $\mathrm{Ca}$ were recorded in sweet potato. In turnip P was observed in lowest concentration. According to current data carrot, eggplant and turnip were also moderately rich source of minerals $(\mathrm{Ca}, \mathrm{K}, \mathrm{Mg}, \mathrm{Fe}, \mathrm{Cu}$ and $\mathrm{Zn}$ ) that was in accordance to previous studies (Sharma et al., 2012; Zaccari et al., 2015).

\section{Table 2. Mineral composition of selected vegetables (mg/100g)}

\begin{tabular}{|c|c|c|c|c|c|c|c|c|c|c|c|c|c|}
\hline Name & $\mathrm{Cu}$ & $\mathrm{Pb}$ & $\mathrm{Co}_{0}$ & $\mathrm{Zn}$ & $\mathrm{Fe}$ & $\mathrm{Cr}$ & $\mathrm{Ni}$ & $\mathrm{Na}$ & $\mathrm{K}$ & $\mathrm{Ca}$ & $\mathrm{p}$ & $\mathrm{Mg}$ & Xn \\
\hline $\begin{array}{l}\text { Sireet } \\
\text { potato }\end{array}$ & $336=0.1$. & $0.08=1.6$ & $0.80=0.1$ & J. $B=0.1$ & $3: 2601.12$ & 0.170 .1 .1 & $0.80=0.1$ & 50.100 .5 & 9060.010.0II & 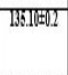 & 48.4000 .1 & \begin{tabular}{|l}
$27.6 \mathrm{OVO} .1$ \\
\end{tabular} & $0.29=0.1$ \\
\hline Fenugreet & 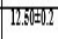 & 12001.2 & 19v0D.1. & $18.10=1.1$ & {$[10,001.2$} & 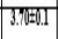 & 4.6010 .12 & $12033(10.1 .5$ & 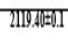 & 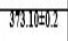 & \$1.81010.5 & 31.2101.12 & $0.1+1=1.1$ \\
\hline Carrot & $6200=1.3$ & $1.00=0.0$ & 1.80DI. & $730=1.1$ & 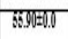 & 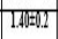 & 1800.1 & T1886060.4 & 2089.60101 .3 & 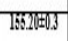 & \begin{tabular}{|l|}
32.2010 .1 \\
\end{tabular} & 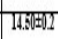 & 31600.1 \\
\hline Bringle & 10.010 .12 & 1.1002 .1 .1 & $0 . Y=0.1$ & 8.200 .12 & (86.01)=1.0. & 1.8020 .1 .1 & 1110.1 .0 & 325.1(10). & $210 \%: B=1.1$ & 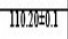 & $24.60=0.1$ & 16.1010.11 & 0.152 .1 .1 \\
\hline Turaip & 12.010.4 & \begin{tabular}{|l|} 
OXNDD.1. \\
\end{tabular} & JS:DED.I & 12.40 .0 .1 & 63.8010 .1 .1 & उoval. & S. MVI. & \begin{tabular}{|l}
260.201 .01 \\
\end{tabular} & 2864.80101 .4 & 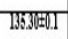 & \begin{tabular}{|l}
30.1010 .3 \\
\end{tabular} & \begin{tabular}{|l}
$2.30 \mathrm{ND} .1$ \\
\end{tabular} & $0,350.1$ \\
\hline
\end{tabular}

The remaining nutrients including $\mathrm{Ni}, \mathrm{Cr}, \mathrm{Mn}, \mathrm{Pb}, \mathrm{Ni}$ and $\mathrm{Co}$ had negligible concentration levels. It has been reported that for many plant species $\mathrm{Cr}$ proved to be toxic at $5 \mathrm{mg} / \mathrm{L}$ (Hussain et al., 2009). In this regard, all the studied vegetables have very low concentration of $\mathrm{Cr}$ as compared to that of reported level for toxicity in plants. In case of the $\mathrm{Pb}$ concentration, the suggested concentration in plant species is $2-6 \mathrm{mg} / \mathrm{L}$ (Hussain et al., 2009). However, the plant species under investigation carries very lesser level of $\mathrm{Pb}$, which further clarifies their use as food supplement (Akinyele and Shokunbi, 2015).

\subsection{Phytochemical analysis of selected vegetables}

Phytochemicals are compounds, derived from plants hypothesized to confer disease protective characteristic (Berma et al., 2013). They exhibit extensive potential as antioxidants (Khan et al., 2013) antimicrobial agents (Das, 2012), anticancer (Amadi et al., 2013), boosts immune system, decrease platelets aggregation and modulates hormone metabolism. In present study, preliminary screening of phyto-constituents revealed a significant presence of alkaloids, saponins, tannins, flavonoids and $\beta$-carotene in all the selected vegetables samples. In quantitative analysis (Table 3) Among the selected vegetables highest amount of alkaloids were obtained from fenugreek $(0.07$ $\mathrm{mg} / \mathrm{g}$ ) while least were determined for eggplant $(0.01 \mathrm{mg} / \mathrm{g})$. In remaining plants the order of crude alkaloids content $(\mathrm{mg} / \mathrm{g})$ lie as given carrot> turnip >s. potato ranging from 0.04 to $0.02(\mathrm{mg} / \mathrm{g})$.

Plants saponins known as natural antibiotics (Raju and Rao, 2012) were also present in fenugreek $(38.78 \mathrm{mg} / \mathrm{g})$ in high amount while least value was estimated for eggplant $(11.63 \mathrm{mg} / \mathrm{g})$. In term of quantity for saponins the difference in selected vegetables was as follows: fenugreek>carrot> turnip> s. potato> eggplant. Tannins have also been recognized due to their therapeutic potential. Lowest amount of tannins was reported in carrot $(7.45 \mathrm{mg} / \mathrm{g})$ while fenugreek once again at the top of the list with highest value $(37.42 \mathrm{mg} / \mathrm{g})$ as shown in Table 4.6. Fruits and vegetables contain 
different types of carotenoids in different extents; act as potential antioxidants and a key to preserving health and avoiding different ailments (Krinsky and Johnson, 2005). Dietary $\beta$ carotenes have a potential in vitamin synthesis within the human body (Omodamiro et al., 2013). The results of present study conferred that all the selected vegetables are rich source of $\beta$-carotens ranging from $0.01-0.02(\mathrm{mg} / \mathrm{g})$. In a previous reports, Fesco and Boudion, (2002) suggested that carrots, sweet potatoes and leafy vegetables contain high levels of $\beta$-carotene, usually exceeding 8000 I.U. per $100 \mathrm{~g}$ and can therefore cover the recommended daily intakes (5000 to 25000 I. U. ).

Table 3. Quantitative analysis of phyto-constituents $(\mathrm{mg} / \mathrm{g})$ of selected vegetable

\begin{tabular}{|c|c|c|c|c|c|}
\hline Scientific Name & Common names & Alkaloids & Tannins & Saponins & $\beta$-carotene \\
\hline I. batatas & S. potato & $0.02 \pm 0.01$ & $13.51 \pm 0.61$ & $21.94 \pm 0.23$ & $0.01 \pm 0.25$ \\
\hline T. foemum-graecum & Fenugreek & $0.07 \pm 0.51$ & $37.42 \pm 0.52$ & $38.78 \pm 0.25$ & $0.01 \pm 0.25$ \\
\hline D. sarota & Carrot & $0.04 \pm 0.72$ & $7.45 \pm 0.21$ & $28.34 \pm 0.54$ & $0.02 \pm 0.46$ \\
\hline S. Melongens & Eggplant & $0.01 \pm 0.35$ & $11.91 \pm 0.17$ & $11.63 \pm 0.58$ & $0.01 \pm 0.27$ \\
\hline B. raparapa & Turnip & $0.03 \pm 0.37$ & $16.64 \pm 0.25$ & $23.82 \pm 0.19$ & $0.01 \pm 0.24$ \\
\hline
\end{tabular}

\subsection{Antioxidative potential of selected vegetable extracts}

\subsubsection{Total phenolic and flavonoid contents of selected vegetables}

Phenolics have also attracted the researchers for their use in different biological activities (Atta et al., 2016). The total phenolic (TPC) and total flavonoid content was markedly higher in Trigonella foenum-graecum (18.45 $\pm .02 \mathrm{mg} \mathrm{GE} / \mathrm{g}$ and $7.61 \pm 0.70 \mathrm{mg} / \mathrm{g}$ respectively) among all the vegetables which signifies its highest antioxidant activity. Solanum Melongena had a moderate $(5.96 \pm .12 \mathrm{mg} / \mathrm{g}$ ) while Daucus carota, Ipomoea batatas and Brassica rapa rapa were showed minimum and almost same TPC content respectively. Depending upon flavonoid contents order of different vegetables lies as Trigonella foenum-graecum $>$ Ipomoea batatas $>$ Solanum Melongena $>$ Daucus carota $>$ Brassica rapa rapa respectively (Table 4). Previously, similar studies of Aqil et al. (2006) and Ramya et al. (2011) have been reported the TPC value of methanol $(74.33 \pm 5.13 \mathrm{mg} / \mathrm{g}$ GAE) and ethanolic ( $4.9 \mathrm{mg} / \mathrm{g}) \mathrm{T}$. foenum-graecum leaf extracts which differ from current value. Differences between the results may be due to differences in ecological conditions such as climate, temperature, location, diseases and pest exposure within the species, choice of parts tested, time of taking samples, and methods of determination (Singh et al., 2014).

Table 4. Antioxidant potential of selected vegetables extracts by different assays

\begin{tabular}{|c|c|c|c|c|c|c|}
\hline $\begin{array}{l}\text { Sr. } \\
\text { No }\end{array}$ & Scientific Name & $\begin{array}{l}\text { Common } \\
\text { Name }\end{array}$ & $\mathrm{TPC}(\mathrm{mg} / \mathrm{g})$ & $\mathrm{TFC}(\mathrm{mg} / \mathrm{g})$ & $\begin{array}{c}\mathrm{DPPH}\left(\mathrm{IC}_{50}\right. \\
\mathrm{mg} / \mathrm{g})\end{array}$ & R. Power \\
\hline 1 & Ipomosa batatas & Sweet potato & $3.91 \pm .07^{\mathrm{a}}$ & $2.53 \pm 0.11^{\mathrm{a}}$ & $0.718 \pm 0.12^{\mathrm{a}}$ & $1.37 \pm 0.13^{b}$ \\
\hline 2 & $\begin{array}{l}\text { Trigonella } \\
\text { foenum-graecum }\end{array}$ & Fenugreek & $18.50 \pm .02^{d}$ & $7.61 \pm 0.70^{d}$ & $0.190 \pm 0.11^{a}$ & $3.44 \pm 0.05^{d}$ \\
\hline 3 & Daucus carota & Carrot & $3.06 \pm .01^{2}$ & $0.26 \pm 0.51^{\mathrm{a}}$ & $0.229 \pm 0.01^{\mathrm{a}}$ & $1.61 \pm 0.10^{c}$ \\
\hline 4 & $\begin{array}{l}\text { Solanum } \\
\text { Melongena }\end{array}$ & Eggplant & $5.96 \pm .12^{b}$ & $0.21 \pm 0.41^{\mathrm{a}}$ & $0.213 \pm 0.06^{\mathrm{a}}$ & $2.16 \pm 0.09^{c}$ \\
\hline 5 & $\begin{array}{l}\text { Rrassica rapa } \\
\text { rapa }\end{array}$ & Turnip & $351 \pm 01^{2}$ & $007 \pm 040^{2}$ & $0879 \pm 012^{a b}$ & $138 \pm 09^{a}$ \\
\hline
\end{tabular}

\subsubsection{DPPH radical scavenging activity vegetables}

Free radical scavenging effects of selected vegetable extracts at various concentrations was determined for their IC50 (mg/mL) relating concentration with percentage inhibition represented in Table 4. All the extracts revealed the proton-donating ability. Extract of T. foenumgraecum was found to be most potent with minimum IC50 $0.19 \mathrm{mg} / \mathrm{g}$ while Brassica rapa rapa was found to be least effective (IC50 $=0.88 \mathrm{mg} / \mathrm{g}$ ). In term of antioxidant activity their order of effectiveness followed $\mathrm{T}$. foenumgraecum $>$ Solanum Melongena $>$ Daucus carota $>$ BHT $>$ Ipomoea batatas $>$ Brassica rapa rapa. The sequence of effectiveness of radical scavenging by DPPH method showed that studied samples could be used as effective antioxidants.

\subsubsection{Reducing power assay of selected vegetables}

Among the tested vegetables, the strongest antioxidant property as depicted by the reducing power assay was also observed in T. foenumgraecum $(3.44 \pm 0.05)$, which could be due to the presence of total phenolics and flavonoids with respects to other extracts followed by the Solanum Melongena. Daucus carota extract showed moderate while Ipomoea batatas and Brassica rapa rapa gave lowest activities among the samples varied ranging from $1.37 \pm 0.13$ to $3.44 \pm 0.05$ in the ascending order (Table 4.). Sathisha et al. (2011) hypothesized that the reducing power of a compound may serve as a significant indicator of its potential antioxidant activity. Previous reports on the relationship between the TPC and antioxidant capacity demonstrated a linear correlation between TPC and the antioxidant capacity (Nisha et al., 2009; Mishra et al., 2010; Atta et al., 2016).

\section{CONCLUSION}

Keeping in view the results, all the studied vegetables present good nutritional sources with moderate energy values and rich sources of macronutrients and micronutrients, exhibiting the least toxic risks regarding heavy metals. The phytochemical composition revealed the presence of considerable levels of phenolics, flavonoids, alkaloids, and tannins among all the edibles. The biological assay in methanolic extracts of analyzed vegetables also has demonstrated appreciable inhibitory actions against oxidation actions. In this context, nutraceutical worth and exhibiting rich array of biochemicals, nutritional and phytochemicals in of these analyzed edibles especially in T. foenum-graecum, current study also opens new endeavors for the applications of functional/nutraceutical foods and their bioactive moieties as a therapeutic device against maladies and also in the field of nano sciences.

\section{Acknowledgment}

The authors are highly thankful to Higher Education Commission (HEC), Government of Pakistan for the financial support under the indigenous PhD program.

\section{References}

Akinyele I. O. and O. S. Shokunbi. 2015. Concentrations of $\mathrm{Mn}, \mathrm{Fe}, \mathrm{Cu}, \mathrm{Zn}, \mathrm{Cr}$, $\mathrm{Cd}, \mathrm{Pb}, \mathrm{Ni}$ in selected Nigerian tubers, legumes and cereals and estimates of the adult daily intakes. Food Chemistry. 173: 702-708.

Amadi, B., N. Onuoha, C. Amadi, A. Ugbogu and M. Duru. 2013. Elemental, amino acid and phytochemical constitute of fruit of three different species of eggplant. Internatinal Journal of Medicinal and Aromatic Plants. 3(2): 200-203.

Aqil, F., I. Ahmad and Z. Mehmood. 2006. Antioxidant and free radical scavenging properties of twelve traditionally used Indian medicinal plants. Turkish Journal of Biology. 30:177-183.

Association of Official Analytical Chemists International. Official method of analysis of AOAC International. 17th ed. Gaithersburg: Association of Analytical Communities; 2003.

Association of Official Analytical Chemists. Official methods of analysis of AOAC International. 18th ed. Washington DC: Association of Official Analytical Chemists; 2010.

Atta, A., M. A. Sheikh, M. Shahid and T. Khaliq. 2016. Antioxidant and antiglycation potential of polyphenol extracts of selected vegetables from Pakistan. Oxidation Communications. 39(3-I), 2249-2259.

Barros, L., L. Cabrita, M. V. Boas, A. M. Carvalho and I. C. F. R. Ferreira. 2011. Chemical, biochemical and electrochemical assays to evaluate phytochemicals and antioxidant activity of wild plants. Food Chemistry. 127:1600-1608.

Berma, S., D. Singh, P. Verma, D. Soni, A. Gupta and R. Nema. 2013. Review Article Boerhavia diffusa: An Important medicinal plant and their phytochemistry. CMBT Journal of Sciences and Technology. 1(1):01-04. Das, S. 2012. Antimicrobial activity study of ethanolic extract of Boerhaavia diffusa whole plant. Internatinal Journal of Pharmavy \& Life Sciences. 3(10) 2006-2009.

Dike, M. C. 2010. Proximate, phytochemical and nutrient compositions of some fruits, seeds and leaves of some plant species at Umudike, Nigeria. ARPN Journal of Agricultural and Biological Science. 5(1):7-16.

E.F.S.A. 2010. Panel on Dietetic Products, Nutrition, and Allergies Scientific opinion on dietary reference values for carbohydrates and dietary fibre. EFSA Journal. 8 (3): 1462.

Ekholm, P., H. Reinivuo, P. Mattila, H. Pakkala, J. Koponen, A. Happonend, J. Hellstro"m and M. Ovaskainen. 2007. Changes in the mineral and trace element contents of cereals, fruits and vegetables in Finland. Journal of Food Composition and Analysis. 20: 487-495. 
Fesco, 0. L. and 0. W. Boudion. 2002. Food nutrition security for human security, International Conference on Vegetables, On the occasion of the WFS-fyl (World Food Summit - five years later), convened in Rome on 11-13 June 2002.

Gala, B. V. and V. Gujar. 2014. Product development, biochemical, antimicrobial and organoleptic analysis on (Trigonella foenum - graecum) fenugreek seeds and leaves. Plant Sciences Feed. 4 (2): 15-18.

Harborne J. B. 2008. Phytochemical methods: a guide to modern techniques of plant analysis. 3rd ed. New Delhi: Springer Pvt Ltd.

Ho, S., Y. Tung, K. Cheng and J. Wu. 2010. Screening, determination and quantification of major antioxidantsfrom Balanophora laxiflora flowers. Food Chemistry. 122: 584-588.

Hussain, J., A. L. Khan, N. Rehman, M. Hamayun, T. Shah, M. Nisar, T. Bano Z. K. Shinwari and I. Lee. 2009. Proximate and nutrient analysis of selected vegetable species: A case study of karak region, pakistan. African Journal of Biotechnology. 8(12): 2725-2729.

Khan, A. M., R. A. Qureshi, F. Ullah, S. A. Gilani, A. Nosheen, S. Sahreen, M. K. Laghari, M. Y. Laghari, S. Rehman, I. Hussain and W. Murad. 2011 Phytochemical analysis of selected medicinal plants of Margalla Hills and surroundings. Journal of Medicinal Plants Research. 5(25): 6017-6023

Khan, M. S., I. A. Ansari, S. Ahmad, F. Akhtar, A. Hashim and A.K. Srivastava. 2013. Chemotherapeutic potential of Boerhaavia diffusa Linn; A review. Journal of Applied Pharmaceutical Sciences. 3(01):133-139.

Krinsky, N. I. and E. J. Johnson. 2005. Carotenoid actions and their relation to health and disease. Molecular Aspects of Medicine. 26(6): 459-516.

Mishra, N., A. Dubey, R. Mishra, N. Barik. 2010. Study on antioxidant activity of common dry fruits. Food Chem Toxicol, 48, 3316-3320.

Nisha, P., P. A. Nazar and P. Jayamurthy. 2009. A comparative study on antioxidant activities of different varieties of Solanum melongena. Food and Chemical Toxicology. 47: 2640-2644.

Noor, N., Sarfraz, R. A., Ali, S., Shahid, M. 2014. Antitumour and antioxidant potential of some selected Pakistani honeys. Food Chemistry 143, 362-366. Omodamiro, R. M., S. O. Afuape, C. J. Njoku, I. I. M. Nwankwo, T. N. C. Echendu and T. C. Edward. 2013. Acceptability and proximate composition of some sweet potato genotypes: Implication of breeding for food security and industrial quality. International Journal of Biotechnology and Food Science.1(5): 97-101.

Peng, X., Zheng, Z., Cheng, K.-W., Shan, F., Ren, G.-X., Chen, F., \& Wang, M. (2008). Inhibitory effect of mung bean extract and its constituents vitexin and isovitexin on the formation of advanced glycation endproducts. Food Chemistry, 106(2), 475-481.

Raju, J. and C. V. Rao. 2012. Diosgenin, a Steroid Saponin Constituent of Yams and Fenugreek: Emerging Evidence for Applications in Medicine, Bioactive Compounds in Phytomedicine. Prof. Iraj Rasooli (Ed.). ISBN: 978-953-307805-2, InTech.

Ramya, P., J. Sudisha, D. N. Lakshmi and S. M. Aradhya. 2011. Antibacterial and Anti-oxidant Activities of Fenugreek (Trigonella foenum graecum L.) Leaves. Research Journal of Medicinal Plant. 5 (6): 695-705.

Sathisha, A. D., H. B. Lingaraju and K. S. Prasad. 2011. Evaluation of antioxidant activity of medicinal plant extracts produced for commercial purpose. E-J. Chem, 8, 882-886 (2011).

Shabbir M, Khan MR, Saeed N. Assessment of phytochemicals, antioxidant, anti-lipid peroxidation and anti-hemolytic activity of extract and various fractions of Maytenus royleanus leaves. BMC Complement Altern Med 2013; 13: 143

Sharma, K. D., S. Karki, N. S. Thakur and S. Attri. 2012. Chemical composition, functional properties and processing of carrot-a review. Journal of Food Science and Technology. 49: 22-32.

Singh, K. P., B. Nair, P. Chand and A. K. Naidu. 2013. Contribution of fenugreek (Trigonella foenum graecum L.) seeds towards the nutritional characterization. Journal of Medicinal Plant Research. 7(41): 3052-3058.

Singh, P., S. P. Vishwakarma and R. L. Singh. 2014. Antioxidant, oxidative DNA damage protective and antimicrobial activities of the plant Trigonella foenum-graecum. Journal Science Food and Agriculture. 94(12):2497-504. Sumayya, A. R., S. Sivagami and A. Nabeelah. 2012. Screening and Biochemical Quantification of Phytochemicals in Fenugreek (Trigonella foenum-graecum). Research Journal of Pharmaceutical, Biological and Chemical Sciences. 3(1):165.

Wang, Y., S. Huang, S. Shao, L. Qian and P. Xu. 2012. Studies on bioactivities of tea (Camellia sinensis L.) fruit peel extracts: Antioxidant activity and inhibitory potential against $\alpha$-glucosidase and $\alpha$-amylase in vitro. Industrial Crops and Products. 37: 520-526.

Zaccari, F., M. C. Cabrera, A. Ramos and A. Saadoun. 2015. In vitrobioaccessibility of $\beta$-carotene, $\mathrm{Ca}, \mathrm{Mg}$ and $\mathrm{Zn}$ in landrace carrots(Daucus carota, L.). Food Chemistry. 166: 365-371.

Zhang, L. Z., Liu, R. H. (2015). Phenolic and carotenoid profiles and antiproliferative activity of foxtail millet. Food Chemistry 174, 495-501. Zia-Ul-Haq, M., Riaz, M., De Feo, V., Jaafar, H. Z., Moga, M. 2014. Rubus fruticosus L.: constituents, biological activities and health related uses. Molecules 19(8), 10998-11029.

Shahidi, F. 2009. Nutraceuticals and functional foods: whole versus processed foods. Trends in Food Science and Technology. 20: 376-387.

Ahmad, S., M. Garg, E. T. Tamboli, M. Z. Abdin and S. H. Ansari. 2013. In vitro production of alkaloids: Factors, approaches, challenges and prospects. Pharmacognosy Reviews. 7(13): 27-33. 